DEMOCRACY AND POPULISM 
BOOKS BY JOHN LUKACS

The Great Powers and Eastern Europe

Tocqueville: The European Revolution and

Correspondence with Gobineau (editor)

A History of the Cold War

Decline and Rise of Europe

A New History of the Cold War

Historical Consciousness

The Passing of the Modern Age

A Sketch of the History of Chestnut Hill College, 1924-1974

The Last European War, 1939-1941

1945: Year Zero

Philadelphia: Patricians and Philistines, 1900-1950

Outgrowing Democracy: A History of the

United States in the Twentieth Century

Budapest 1900: A Historical Portrait of a City and Its Culture

Confessions of an Original Sinner

The Duel: 10 May-31 July; The Eighty-Day

Struggle Between Churchill and Hitler

The End of the Twentieth Century and the End of the Modern Age

Destinations Past

George F. Kennan and the Origins of Containment, 1944-1946: The Kennan-Lukacs Correspondence

The Hitler of History

A Thread of Years

Five Days in London, May 1940

A Student's Guide to the Study of History

At the End of an Age

Churchill: Visionary. Statesman. Historian.

A New Republic 


\section{JOHN LUKACS}

\section{Democracy and}

Populism

\section{Fear \& Hatred}

$$
\text { है }
$$

Yale University Press NEW HAVEN \& LONDON 
Copyright (c) 2005 by John Lukacs.

All rights reserved.

This book may not be reproduced, in whole or in part, including illustrations, in any form (beyond that copying permitted by Sections 107 and 108 of the U.S. Copyright Law and except by reviewers for the public press), without written permission from the publishers.

Designed by James J. Johnson and set in Minion types by Integrated Publishing Solutions

Printed in the United States of America by R.R. Donnelley \& Sons

Library of Congress Cataloging-in-Publication Data

Lukacs, John, 1924-

Democracy and populism : fear and hatred / John Lukacs

p. $\mathrm{cm}$.

Includes index

ISBN 0-300-10773-o (alk. paper)

1. Political science-United States-History-2oth century. 2. United StatesPolitics and government—2oth century. 3. Ideology_-United States-History2oth century. I. Title.

JA84.U5L85 2005

$320.5^{\prime} 0973^{\prime} 0904-\mathrm{dc} 22$

2004058450

A catalogue record for this book is available from the British Library.

The paper in this book meets the guidelines for permanence and durability of the Committee on Production Guidelines for Book Longevity of the Council on Library Resources.

$\begin{array}{llllllllll}10 & 9 & 8 & 7 & 6 & 5 & 4 & 3 & 2 & 1\end{array}$ 